\title{
Charcoalified plant remains from the Lashly Formation of Allan Hills, Antarctica: Evidence of forest fire during the Triassic Period
}

1 Birbal Sahni Institute of Palaeobotany, 53 University Road, Lucknow-226007, India.E-mail: madhavbsip@yahoo.com; rajni.tewari@gmail.com; mehrotrabsip@rediffmail.com.

2 Texas Tech University, Lubbock, Texas, USA.E-mail: sankar.chatterjee@ttu.edu

Microscopic charcoal preserved in sediments of the Lashly Formation (Middle to Late Triassic) of South Victoria Land (SVL), Antarctica provides a proxy record of palaeofire. These charred fragments derived from wood and leaf pieces along with spores and pollen grains are part of the buried plant biomass preserved in the shale and carbonaceous shale of fluvial/lacustrine deposits. The evidence of paleofire in Antarctica during the Triassic Period is supported by the presence of a thin bed of silicic tuff interlayered with Dicroidiumbearing shale. The detailed morphology and comparative anatomy of least to high thermally altered plant fragments observed under the light, fluorescence and scanning electron microscope demonstrates the evidence of effect of fire on the vegetation during Middle to Late Triassic (240-200 million years). Most of the charred particles retain identifiable structures with well-preserved to distorted cellular details. Such plant fragments are dark brown, blackish brown, quadrangular-multiangular, equi-dimensional, opaque up to the edges and nonfluorescent. The pollen grains recorded from several sedimentary sequences (but the new data come from only one level i.e., member C of Lashly Formation) show distorted exinal sculptures and are light to dark brown in colour indicating intensive thermal effect. The detailed microscopic images of such fire-affected plant remains also explain their preservation biases in the sediments. The magnitude of the charred pieces and their abundance peaks from various locations in Allan Hills is related solely to the production and amount of burnt material embodied in the sediments. The high peaks indicate severity of fire and production of maximum charcoal of the standing vegetation in Allan Hills.

\section{Introduction}

The vegetation, climate and various constructive and destructive factors have been closely interconnected in an ecosystem since Late Paleozoic times. This vegetation-climate dynamics is considered exceedingly significant for the interpretation of palaeoenvironment and other ecological factors. The devastation of vegetation by storms, floods, fire and volcanic eruptions produces huge amounts of plant biomass. This biomass is preserved in sediments and provides critical insights into such catastrophic events. Various evaluating methods for detecting forest fire based on the microscopic charcoal analysis have been developed.

During the Phanerozoic, especially after Devonian, the interaction between vegetation and fire in various ecosystems has been identified by studying the charcoalified plant remains viz., micro and megascopic pieces of leaves, shoots, woods and thermally altered spores and pollen grains. The burnt biomass displays a range of mega and microscopic forms of carbonized particulate material which are strong indicators of forest fire (Patterson et al., 1987; Whitlock and Larsen, 2001). These are also known as charcoal, soot, black carbon, microcrystal, graphite or elemental carbon (Bird, 1997) fusinite and semifusinites (Stopes, 1919 sensu Scott and Glasspool, 2007). Charcoal is chemically inert, light weight and highly resistant to microbial decay and sometimes retains identifiable anatomical details. Even under highly oxidized environment, extraordinary preservation of threedimensional outer and cellular morphology of the fragmented charred plants is clearly visible (Lupia, 1995). It remains largely intact when transported as bed load of finer clastic sediments to long distances (Blong and Gillepse, 1978). Preservation of various types of cellular (well structured, least to moderately degraded plant fragments) and thermally altered (brown, dark brown, black, opaque, lath shaped, cellular, non-cellular) morphological features provides an unique palaeoenvironmental information on pre-burial and burial conditions of the sedimentary deposits.

In the present investigation, light, fluorescence and scanning electron microscopic analysis of charcoalified remains of various plant organs has been carried out which suggests a fire event. The ratio of charcoalified and non-charcoalified tissues are quantified by counting each type of sedimentary organic matter including spores and pollen grains in the palynological slides of all productive samples. The light microscopic study of such thermally altered plant fossils exhibits blackening and distortion of spores, pollen and structured phytoclasts which is usually caused by the effect of high temperature. The woody pieces display shrinkage, distortion, cracking and rupture in their cellular organization e.g., pits and other vascular tissues. Abundance of small charcoalified pieces in all samples also indicates fire activity. Thinly bedded silicic tuff layer associated with the Dicroidium-bearing 
shale beds clearly indicates synchroneity between volcanism and Triassic vegetation in Allan Hills. These records manifest regional fire-vegetation-climate relationship and are helpful in interpretation of palaeoecological reconstructions. The charred (due to flame convections) and the uncharred plant material and its accumulation towards depositional sites provides evidence of burning of plant biomass. Similar observations have also been made by Cantrill et al. (1995) from Prince Charles Mountain, East Antarctica and Van de
Schootbrugge et al. (2009) who have suggested volcanic activity as a reason for the forest fire.

\section{Material and Methods}

Samples for present study have been collected from Lashly Formation (Triassic) of Allan Hills (latitude $76^{\circ} 43^{\prime} \mathrm{S}$, longitude $159^{\circ}$ 40'E), Victoria Land, Central Transantarctic Mountains, Antarctica

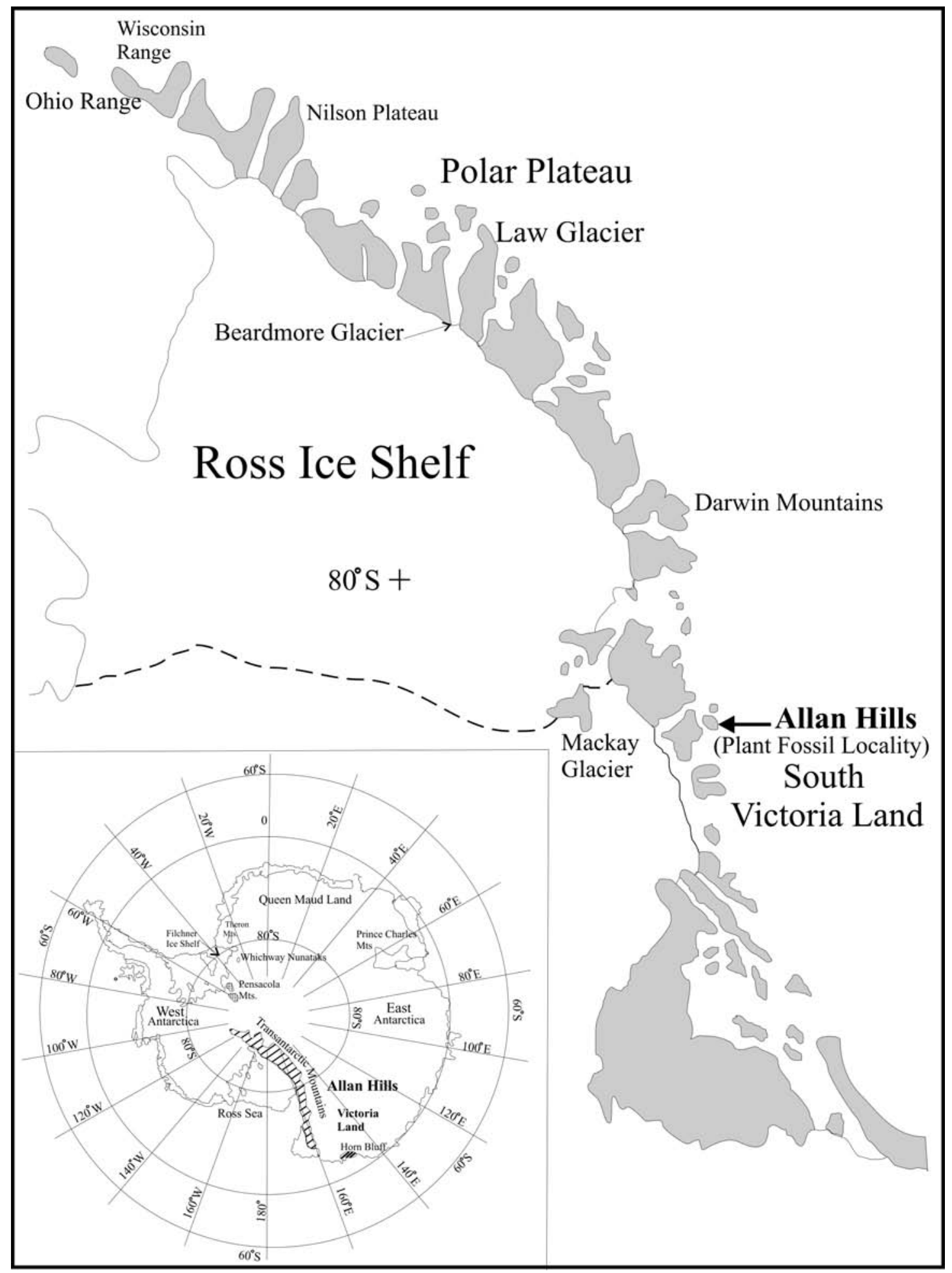

Figure 1. Map showing Allan Hills, Victoria Land, Central Transantarctic Mountains (after Kyle 1977). (Plant fossil locality is marked by an arrow). 


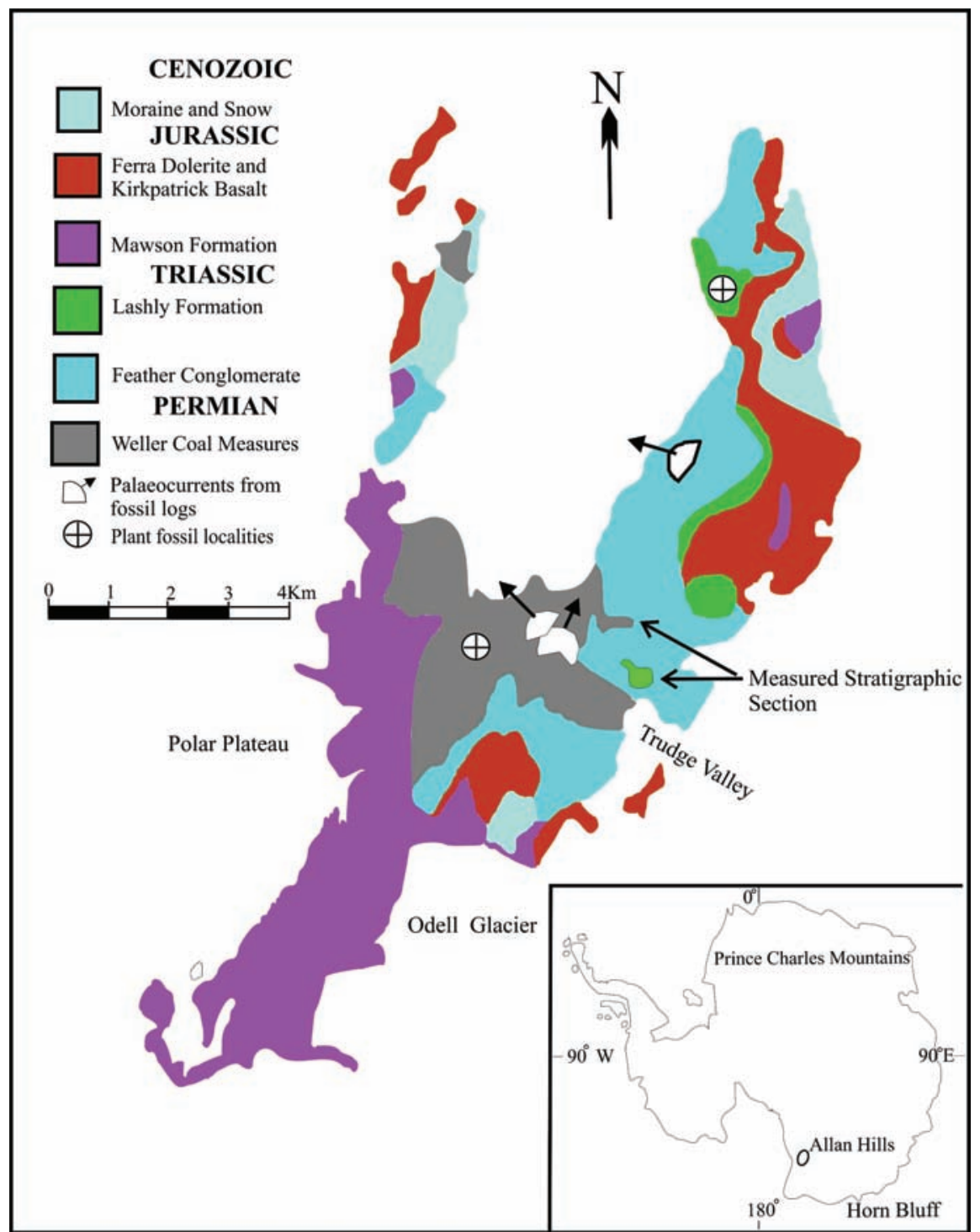

Figure 2. Geological map showing plant fossil locality.

(Figures 1-3) by one of the authors (SC) and his field team during the Antarctic field season in 1982-1983. The collection is presently housed at the Museum of Texas Tech University, Lubbock, Texas. About 15 shale samples of well-preserved plant fossils from exposed strata of Lashly Formation, Allan Hills containing rich impressions of Dicroidium and other taxa are used for the present study. Small pieces of shale were chemically processed by standard palynological techniques for recovery of spore-pollen, microscopic charcoal and other sedimentary organic matter (SOM). About 30 grams of each sample was digested in $40 \%$ hydrochloric and hydrofluoric acids, respectively. The acid-free digested material was then treated with aqueous ammonia solution. Concentrate nitric acid was added to the undigested residue for removal of the humic matter followed by treatment with 3-5\% potassium hydroxide aqueous solution. The aciddigested material was stirred gently with a glass rod to avoid further breakage of charcoalified plant pieces. The residue containing rich microscopic charcoal was used for preparation of palynological slides which were studied under light and UV fluorescence microscope. The remaining material was further used for detailed morphological study under LEO 430 digital scanning electron microscope. The charcoalified residue was mounted on aluminium stubs and coated with gold-paladium alloy. For a quantitative analysis of charcoalified plant fragments, 500 counts of sedimentary organic matter per sample were taken. The percentage frequency of charcoalified, structured terrestrial (noncharcoalified root, stem and leaf tissues without any alterations) and biodegraded terrestrial (least to highly degraded) organic matter recovered from the green and black shales (collected from two locations which are two km apart) are plotted to compare abundance of charcoalified remains (Figures 4A, B). The specimens studied under light and scanning electron microscopes are shown in Figures (5-9). All the slides are deposited in the repository of the museum of Birbal Sahni Institute of Palaeobotany, Lucknow for further reference.

\section{Geology of the area}

The Gondwana system exposed at Allan Hills, South Victoria Land consists of flat-lying continental sediments ranging in age from Permian to Jurassic. In this horizon two units are recognized viz. (i) a lower unit of the Victoria Group, which consists mainly of fluvial clastic sediments, and (ii) an upper unit - the Ferrar Group which is volcanic in origin. The stratigraphy of Allan Hills has been discussed by Gunn and Warren (1962), Borns and Hall (1969), Barrett et al. (1971), Barrett and Kohn (1975), Balance (1977) and Kyle (1977). The Lashly Formation gradationally overlies the Feather Conglomerate and contains plant remains of the Dicroidium flora throughout. The formation is composed of four members viz., (i) member A at the base is a cyclic sequence of fine grained sandstone and green siltstone; (ii) member $\mathrm{B}$ is predominantly medium grained sandstone; (iii) member $\mathrm{C}$ is interbedded sandstone and carbonaceous siltstone and (iv) member $\mathrm{D}$ principally consists of medium grained sandstone. Member $C$ contains a thin bed $(\sim 5 \mathrm{~cm}$ thick) of silicic tuff interlayered with the Dicroidium-bearing shale indicating a proximate source of volcanism. The tuff layer shows fine bedding and contains abundant glass material and fragments of other rocks and fossils. The Triassic strata are overlain disconformably by the Mawson Formation (Early Jurassic) of the Ferrar Group. The Mawson Formation consists mainly of diamictite. It is overlain by the Ferrar Formation which is Late Jurassic in age (Chatterjee et al., 1983) and shows intrusions of sills and dykes of the Ferrar dolerite. The stratigraphic column of Victoria Group in South Victoria land is given in Figure 3 (modified after Kyle, 1977).

\section{Records of forest fire during geologic past}

Evidences of fire, based on fossil charcoal (micro, mega, fusinites and semifusinites), are reported from Silurian onwards by Edwards and Axe (2004) and Glasspool et al. (2004) during the Phanerozoic Eon. Cressler (2001) recorded evidence of palaeofire in the Late 
LEGEND

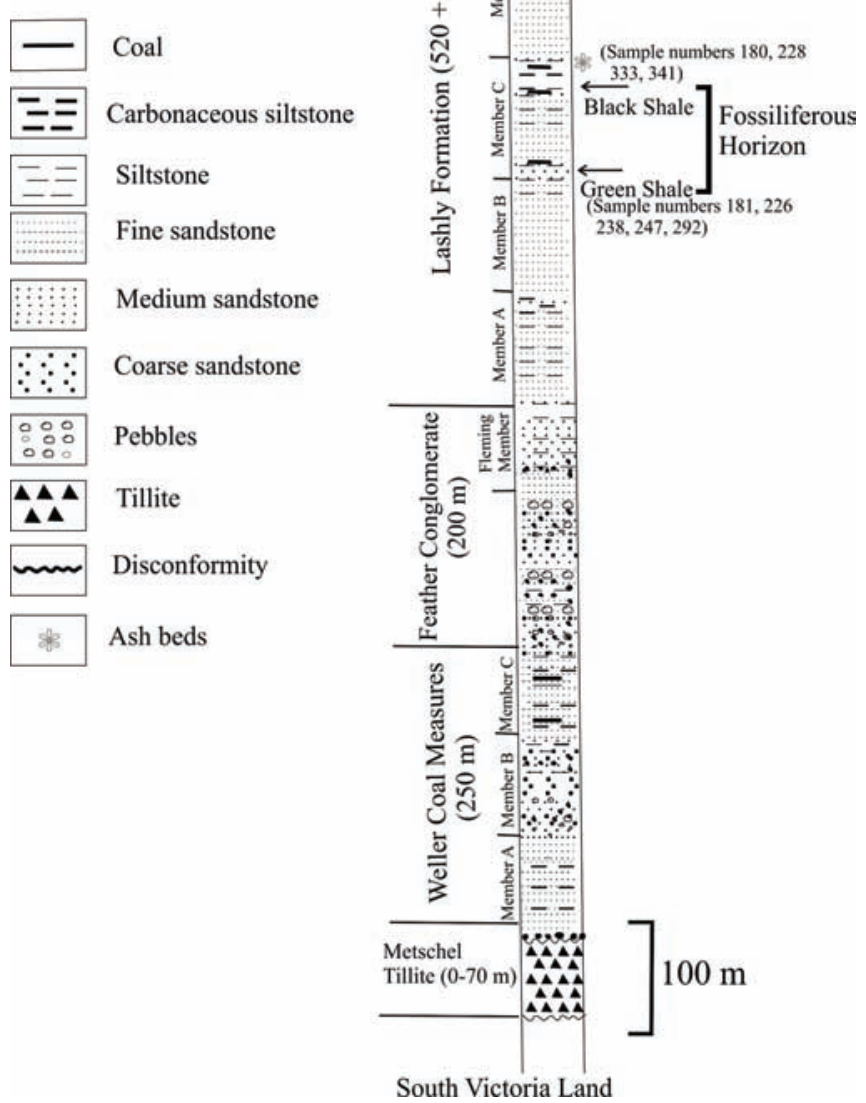

Figure 3. Composite sratigraphic column of the Victoria Group in South Victoria Land (after Kyle, 1977). Arrows indicate plant fossil horizons and sample numbers within the Member $C$ of the Lashly Formation.

Devonian terrestrial ecosystem in the Catskill Formation of northcentral Pennsylvania. Scott and Jones (1994) and Nichlos and Jones (1992) recorded wild fire in Mid-Lower Carboniferous near-shore sediments of Donegal, Ireland and Jasper et al. (2008) reported forest fire from Early Permian of Brazil. Uhl et al. (2004) recorded wild fire from Upper Carboniferous to Lower Permian of SW Germany. During Jurassic and Cretaceous, events of fire are reported from Europe by Cope (1993), Scott (2000) and Finkelstein et al. (2005). Besides, charcoal (fusinite) is of common occurrence during Middle to Late Permian coaliferous sediments of different Gondwana continents viz., Antarctica, Australia and India (Mishra, 1996; Mishra et al., 1990).

\section{Causes and consequences of forest fire}

The natural forest fire is a regular phenomenon throughout the geologic periods and is probably caused as a result of lightening strikes, sparks, volcanic activities and eruption of fire balls or extraterrestrial effects (Scott, 2000; Uhl et al., 2004). Ignition by meteoritic bodies is controversial, while lightening strikes occasionally burn the forests. The fire caused by lightening is however, frequently
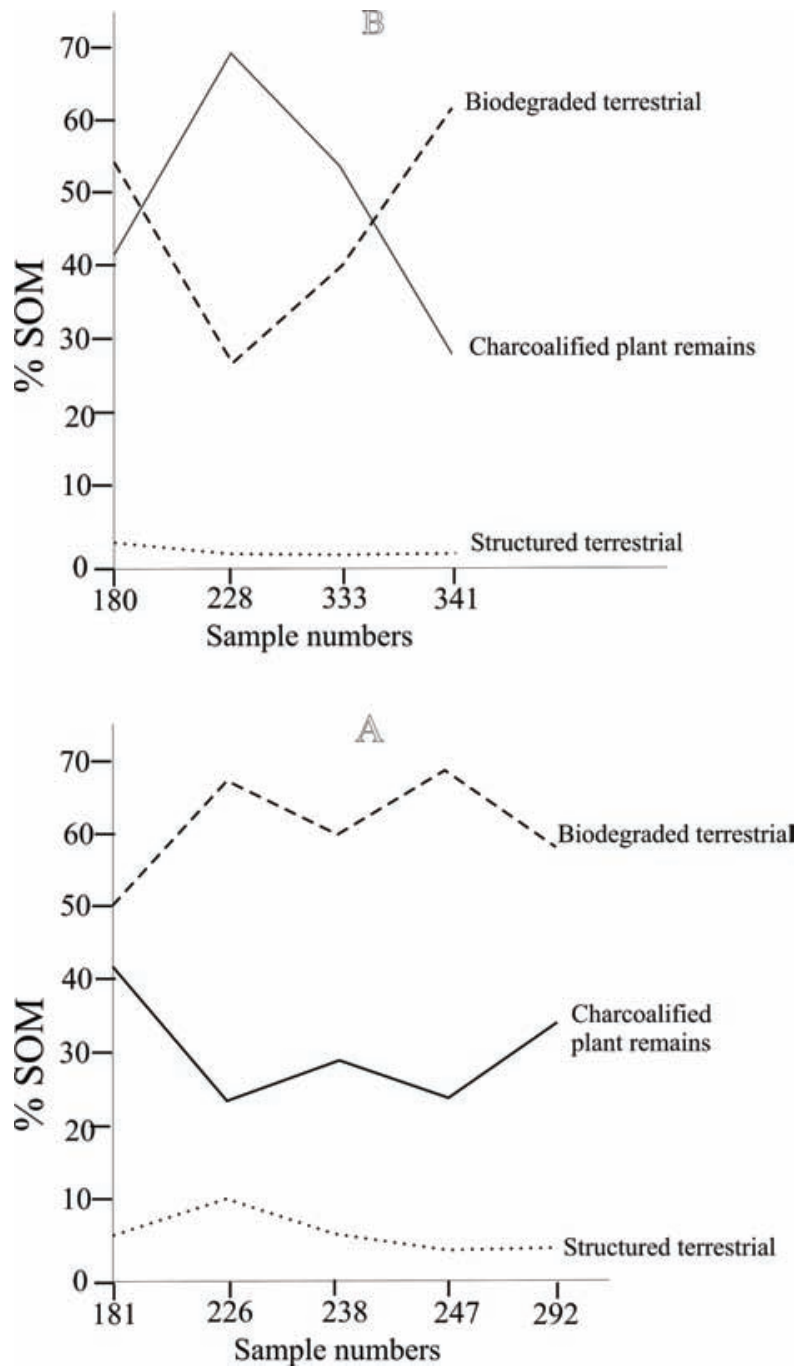

Figure 4. Text figure based on distribution of abundances of charcoal and other sedimentary organic matter (SOM) in green (A) and black shale $(B)$ samples collected from fossiliferous horizon.

ceased by the rains. The lava and other pyroclastic flow may be of great potential for ignition of wild fires (Scott, 2000). Axelrod (1981) opined that stunted vegetation and extinction of many species was due to volcanic ash fall. Flowing of the hot magma or eruptive volcanic bombs which fall on and around a particular area of the forest burn the entire vegetation of that area. The burnt vegetation and plant biomass are preserved in sediments in the form of charcoal. Rich charcoalified facies of Lashly Formation, Allan Hills indicate that standing vegetation in the area was affected by forest fire. This view of forest fire is supported by the sedimentological evidence in Member $\mathrm{C}$ unit such as ash beds (Figure 3), accretionary lapilli and hydrothermal mineralization. Elliot et al. (1986) and Pompilio et al. (2001) observed magmatic bodies of one to more than hundred meters thick in rocks of Victoria Land. These volcanoclastic rocks interbedded with lava from local pillows or pillow-breccias are indicators of active volcanism. According to Elliot et al. (1986) and Pompilio et al. (2001), the volcanic and volcanoclastic material in Lashly and Falla formations in the Transantarctic Mountains came both from craton and volcanic arc. Igneous activity continued in the Ferrar Group representing a Gondwana magmatic province consisting of a thick sequence of volcanic ash and sub-volcanic rocks (Riley and Knight, 2001).The 

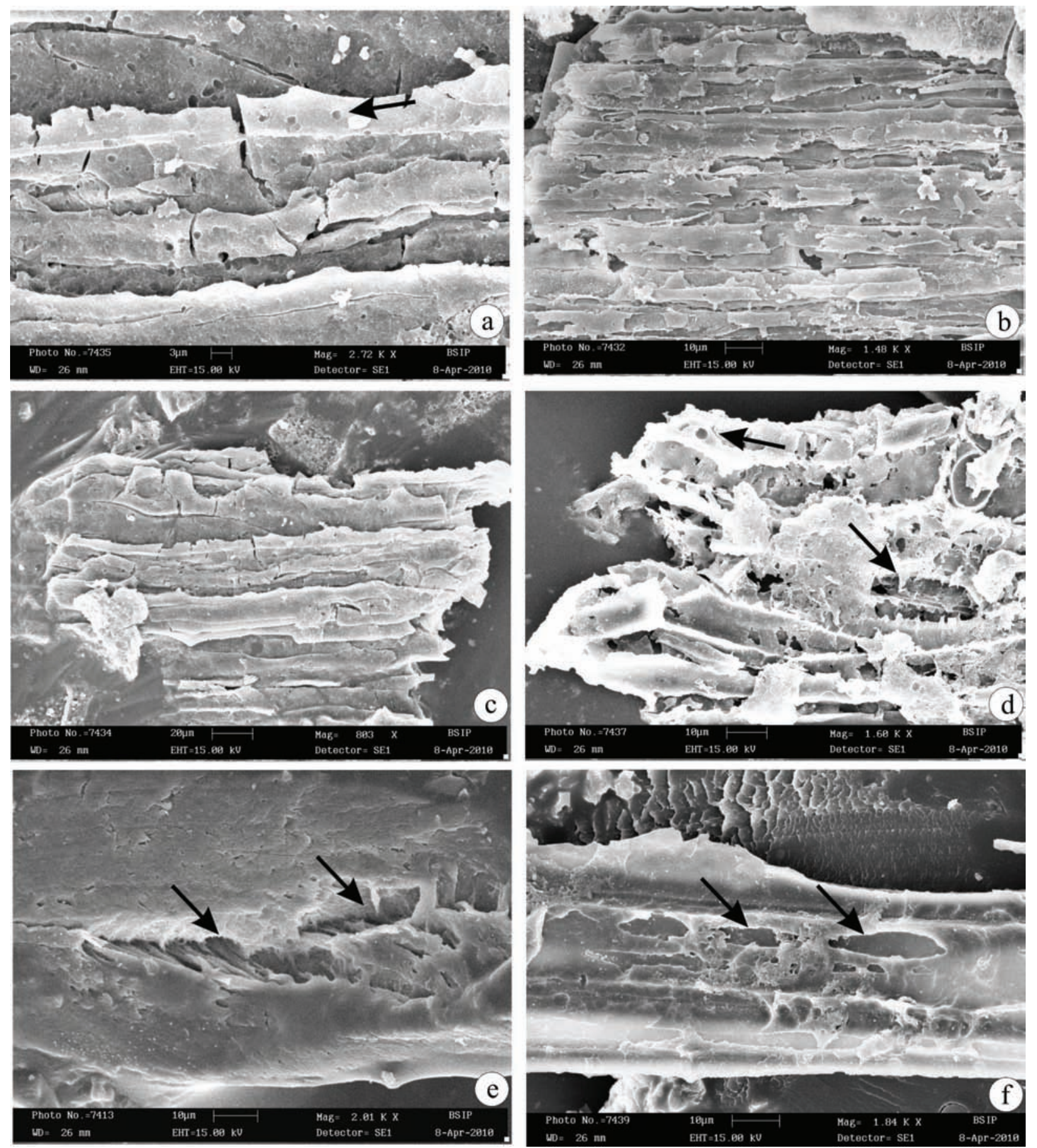

Figure 5. Scanning Electron Microscopic (SEM) images of charcoalified vascular tissues, showing (a) bordered pits and ruptured vascular tissue (indicated by an arrow), (b) general view of ruptured strands, (c) shrunken and ruptured outer layers of vascular tissues, (d) details of uniseriate bordered pits (indicated by an arrow) ruptured layers of tracheids (indicated by an arrow) and their internal structures, $(e)$ and $(f)$ details of rupturing in outer layers of vascular tissues (indicated by arrows).

other evidence of magmatic activities are recorded in volcanic rocks of Antarctica by Riley and Leat (1999) and Schöner et al. (2007). Spalletti et al. (2003) opined that Triassic was a period of explosive volcanic processes which caused destruction of vegetation and soil profiles globally.

Fire ignition requires a source of fuel, heat and oxygen, whereas, its propagation depends on climate and topography (Scott, 2000). It has been observed in the present study that a huge amount of charcoal was generated by the burning of the standing plants and plant litter spread on the forest floor in Allan Hills. The charcoalified facies support the potential role of volcanic/magmatic activities for the ignition of forest fire in this part of Antarctica for a certain period during Middle to Late Triassic.

\section{Types of microscopic charcoal}

Charcoalified plant fragments have been recovered from fifteen 

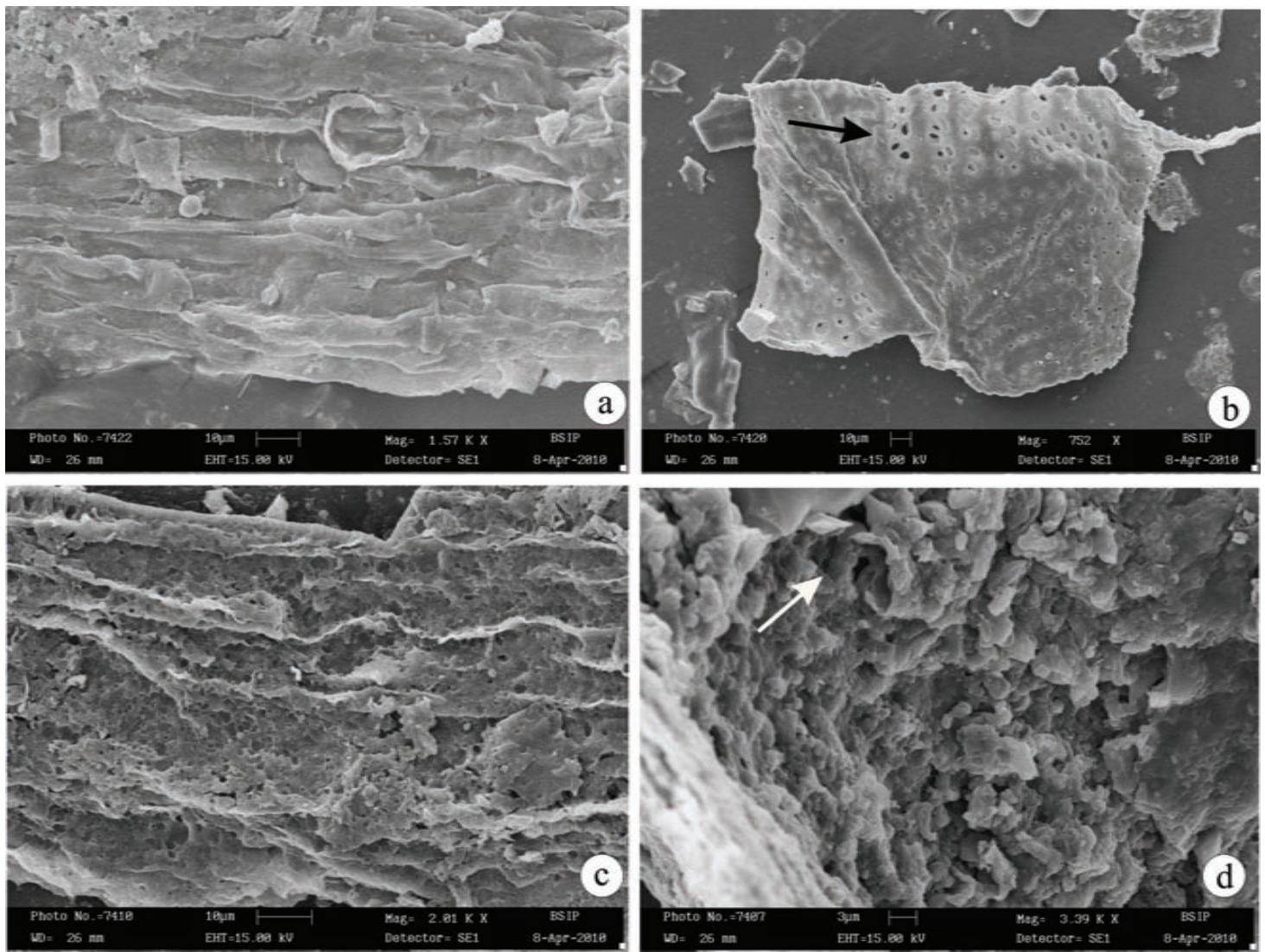

Figure 6. SEM images of charcoalified barks (a) moderately ruptured outer layers of stem, (b) outer layer (membrane) showing pores (indicated by an arrow), (c) parenchymatous vascular strands showing deformity in outer walls (indicated by an arrow), (d) inner surface of unidentified thermally altered fossil tissues showing deformity in cellular structures (indicated by an arrow).
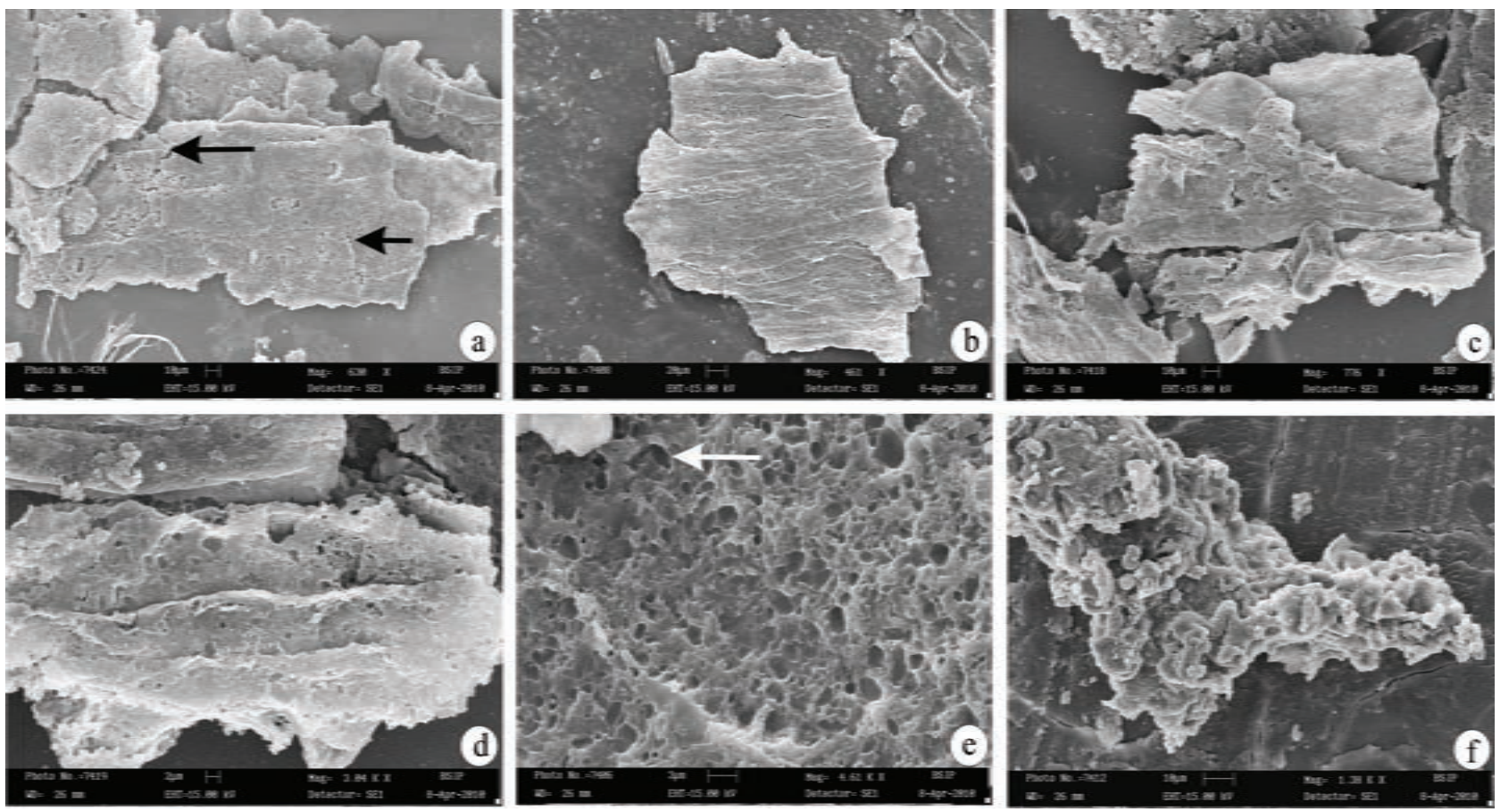

Figure 7. SEM images of leaf fragments showing (a-c) micro cracks (indicated by an arrow) and pores in epidermal layers, (d) fracturing and stretching in epidermal layer showing various size of pores (due to tension on leaf epidermis), (e) highly altered leaf epidermis showing deformity in cellular structures (marked by arrow), $(f)$ thermally altered pteridophytic sporangium showing amalgamation of cellular structures and shrunk spores. 


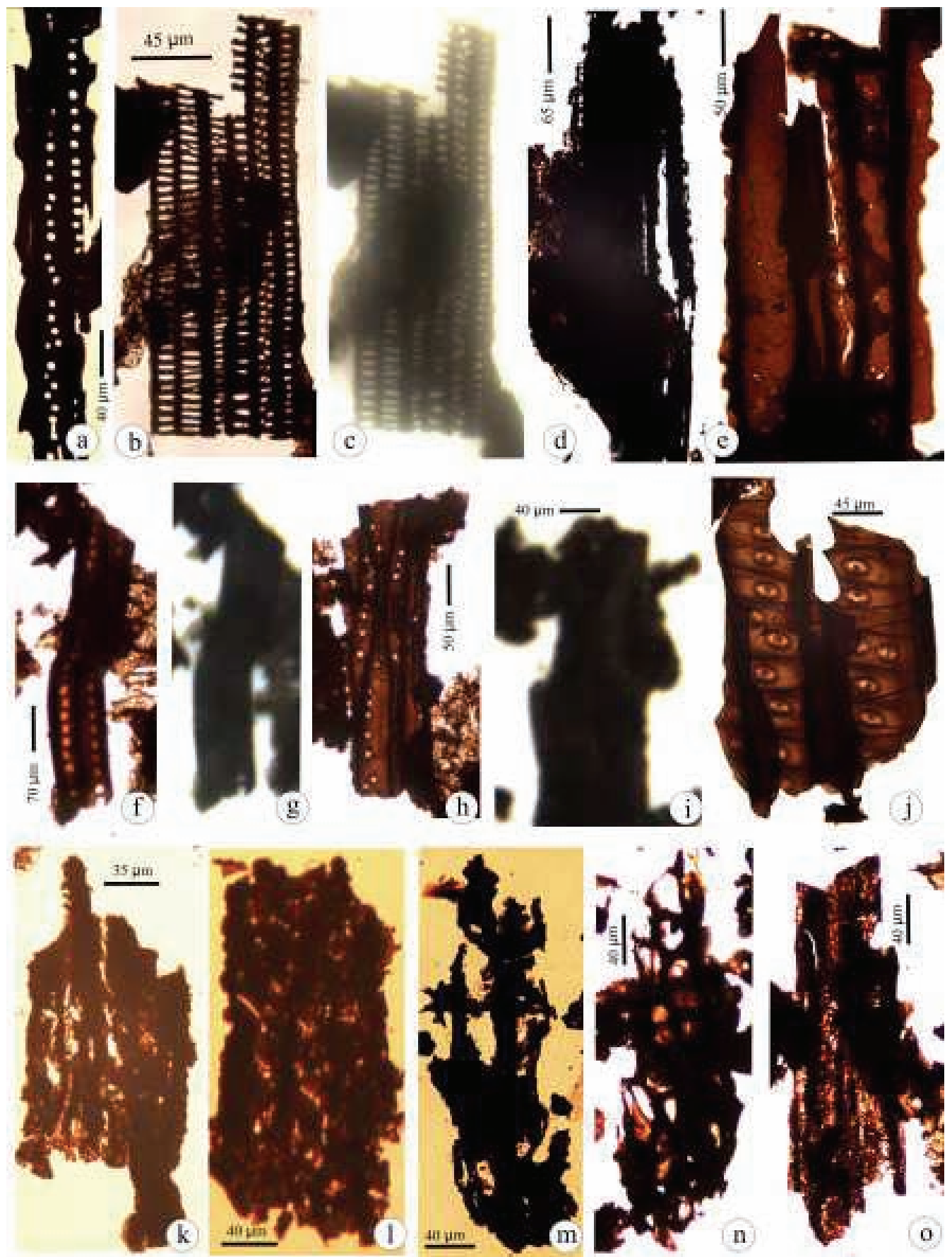

Figure 8. Light microscopic images of charcoalified woody tissues, (a) biseriate bordered pits, slide no. BSIP 13864, V/42, (b) tracheids with scalariform thickenings showing perforated plate and bordered pits, slide no. BSIP 13865, O/34, (c) flourescence image of (b), (d) highly carbonized tissue showing diffused pores and bordered pits, slide no. BSIP 13869, N/34, (e) thermally altered dark brown vascular tissue, slide no. BSIP 13866, O/37, (f) biseriate bordered pits, slide no. BSIP 13869, S/39, (g) flourescence image of $(f),(h)$ dark brown bordered pits, slide no.13869, O/22, (i) flourescence image of $(h),(j)$ araucaroid type bordered pits with thickenings, slide no.13867, N/29, ( $k$-n) highly carbonized bark tissues, slide no. BSIP 13867, (o) parallel lines of diffused perforations in vascular tissue slide no. BSIP 13869.

samples. They show identifiable outer marginal morphology and other internal cellular details. A majority of fragments are derived from arboreal gymnosperms (especially of conifers and cycads) and ferns. However, due to small sizes and absence of distinctive morphological features in charcoalified fragments, their generic/ specific subscription is difficult. Study of the charred plant parts under light, fluorescence and scanning electron microscope shows low to high thermal alteration e.g., darkening, cracking and irregular perforations in the exines of spores, pollen grains, fracturing and distortion in outer layers of bordered pits, tracheids and other vascular tissues (Figures 5-9). Shrinkage and amalgamation of epidermal and hypodermal layers are also noticed. The outer morphology of charred and uncharred phytoclasts indicates their contact with direct flame combustion, heat convection or radiation with various degree of thermal effects prior to, or during their burial and thus, manifests relationship of plants with thermal gradient during the geological processes (Bostick, 1971). Thus, colour of these phytoclasts (structured and non-structured terrestrial sedimentary organic matter) varies from dark yellow, brown, dark brown to black. Besides, some of the fossil tissues which could not be identified due to thermal alteration are also noticed (Figure 6). Additionally, these phytoclasts that are derived from a particular facies type indicate interrelation of plants with the existing environment as well. Their frequency in various samples e.g. in the black shale ranges between 25 and 68 percent and in green shale ranges between 25 and 40 percent (Figure $4 \mathrm{a}, \mathrm{b})$. A brief description of morphological diversity in different charcoalified biological remains is given below.

\section{Type 1 - Charcoalified} remains derived from the woody material

A large number of microscopic charcoal pieces derived from secondary woods are $15 \mu \mathrm{m}$ $2 \mathrm{~mm}$ long and $10 \mu \mathrm{m}-1 \mathrm{~mm}$ wide; quadrangular-multiangular, opaque at the ends, dark brown to black (Figure 8b-8i). Most of the charred vascular tissues display uniseriate or biseriate bordered pittings (Figures 5a, 5d, 8a, 8j). Some cortical tissues show diffused porosity on outer surface of the vessels (Figures 5b, 8d and 8o) and parenchymatous cells. Most of the vessel elements, tracheids and other vascular tissues observed are cracked, fractured, ruptured or 
distorted (Figure 5c-f). The patterns and types of bordered pits and tracheids show affinity with conifers.

\section{Type 2 - Charcoalified remains derived from the barks of stem}

Several fragments of charred barks of various sizes (200-600 $\mu \mathrm{m})$ are also encountered in the assemblages. A number of vertical fimbrils connected to horizontal bars are apparent with simple and compound perforation plates (Figure $6 \mathrm{a}-6 \mathrm{c}$ and $8 \mathrm{n}$ ). The cellular visibility of thermally altered fibers of barks are of common occurrence (Figure 8k-8n).

\section{Type 3 - Charcoalified remains derived from leaves and sporangia}

Charred leaf fragments show several identifiable features that point towards intensive heat radiation e.g., shrinkage of epidermal layers, cracking, damage of the cell wall and distortion of stomatal apparatus (Figure 7a-e). Coalescence of epidermal cells in sporangial wall is also clearly visible in some of the specimens (Figure 7f).

\section{Type 4 - Thermally altered spores and pollen} grains

According to Gray and Boucot (1975), the morphology of pollen and spores displays cracks, shrinkage, perforations and distortion of exinal features due to the effect of high temperature. As a result they loose their size and weight (Ujiié et al. 2003). All the spores (e.g., Crustaesporites trilobatus) and bisaccate pollen grains (e.g., Falscisporites stabilis, Falscisporites sp., Alisporites grobus) identified in the present study and several other unidentified altered spore pollen taxa show these features. The recovered bisaccate pollen grains from the studied sequences show unusual perforations, irregular cracking of the exines and reduction in size of cappa and saccus, and exhibit a remarkable change in their sculpture and dimensions (Figure 9) visible by change in their alveolar exines and biopolymer contents due to effect of intensive heat (Kedves et al., 1992). The monosaccate pollen grains and pteridophytic spores exhibit comparatively less distortion in morphology, but darkening in their colour is a common phenomenon.

Since spores and pollen grains are more sensitive to high temperatures as compared to other plant parts, change in their colour from pale yellow to light and dark brown is noticed when they come in contact with temperature between $150^{\circ} \mathrm{C}$ and $350^{\circ} \mathrm{C}$ for one to four hours or more. This is due to the effect of temperature on the biopolymers of exines and other cytoplasmic contents (Kedves et al., 2000). The sensitivity to heat energy is varied in pollen of different species because of presence of different genotypes, which differentiate them from one another since their developmental stages (Ahmed et al., 1992; Kedves et al. 2000).

\section{Discussion}

Occurrence of rich microscopic charcoal or charred particles
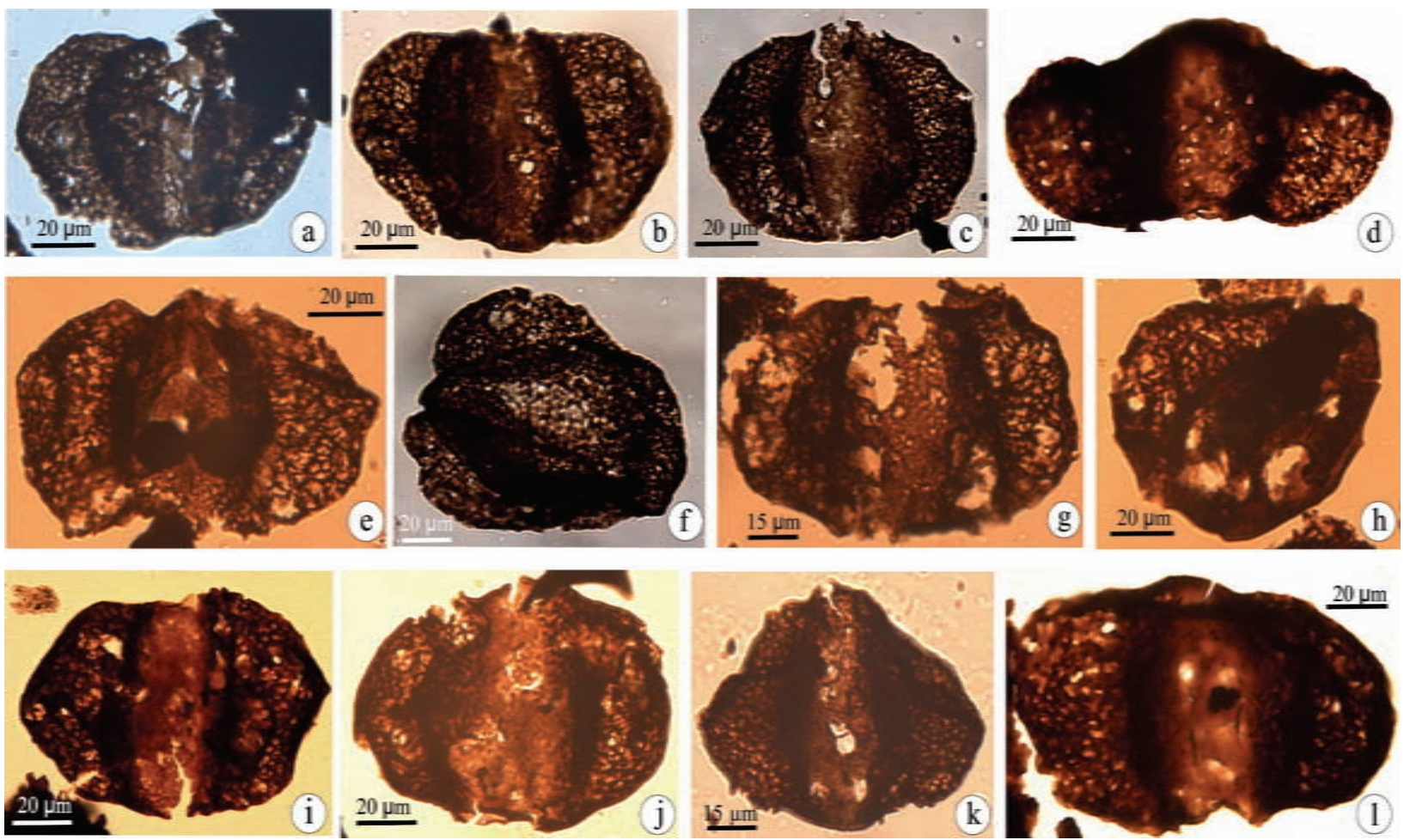

Figure 9. Bisaccate pollen grains showing rupture, shrinkage and deformation of exinal sculpture, (a-c) Falscisporites stabilis Balme, slide nos. BSIP (a) 13868 P/34. (b) 13868 Q/47. (c) 13868, (l) ruptured bisaccate pollen grain showing irregular perforations in central body, slide no. BSIP 13868 R/48, (d), (e) pollen grains showing shrinkage of central body and sacci, (d) Alisporites grobus Bhardwaj and Tiwari slide no. BSIP 13864 S/38, (e) Falscisporites sp. slide no. BSIP 13867 O/29, (f) Crustaesporites trilobatus Venkatachala and Rawat, thermally altered pollen grain, slide no. BSIP 13867, $L / 24,(g-k)$ unidentified thermally altered bisaccate pollen grain showing rupture and deformation of sacci and central body, $(g-j)$ slide no. BSIP 13867, $(k)$ slide no. BSIP $13868 \mathrm{~J} / 28$. 
within the plant-bearing deposits of Allan Hills provides evidence of fire which had severely affected vegetation of the area during Middle to Late Triassic. Shu et al. (2000) also recorded similar type of charcoalified remains from the Late Triassic plant microfossils of the Miers Bluff Formation, Livingston Island, South Shetland Island, Antarctica. Evidently, the fire destroys the standing vegetation/plant litter prior to its burial in sediments and causes devastation of several species, thereby decreasing the plant population. Sporadic records of Dicroidium and other plant fossils (Boucher et al., 1993) from similar beds and poorly preserved spores and pollen grains recorded from carbonaceous shales of the Lashly Formation, also indicate incidence of fire. The close association of silicic tuff layer with the Dicrodium bed in Member $\mathrm{C}$ of the Lashly Formation clearly indicates close genetic link between proximate volcanism and vegetation. In some cases, the tuff enclosed plant material which has transformed into charcoal shows distortion in morphological features. However, cellular details can still be identified in them. The bedded nature of the tuff clearly indicates its contemporaneous deposition with the fossiliferous shale bed and discounts the possibility of its origin in the post-Triassic period, especially during Ferrar volcanism. Uhl et al. (2004, p. 31) opined that close proximity of several charcoal occurrences with tuffs or tuffites supports the potential role of volcanic activities for the ignition of wild fires. However, the extent of this tuff bed and the source of this Triassic volcanism in Alan Hills area are not known.

Records of contemporaneous fossil flora from other parts of Gondwana during Middle to Late Triassic are also poor. According to Kemp (1999) and Spalletti et al. (2000) the stunted vegetation is a consequence of global heating phenomenon associated with intense volcanic activity. The hot magma or eruptive volcanic bombs were the reason for ignition of the forest fire and burning of plant biomass in South Victoria Land. Such charred plant biomass disintegrated into very small pieces during transportation and was preserved in the form of microscopic charcoal in the sedimentary matrix. The charcoalified plant fragments recorded from the black shales show higher frequencies as compared to those derived from green shale beds. The black shales were probably deposited near the source of burnt biomass. The charred fragments also provide a clue to the various degrees of thermal alteration by flaming combustion or convection, intensity and period of burning of the vegetation, production of charred biomasses, its transportation, deposition and often palaeoclimatic interferences in the sedimentary basin.

\section{Acknowledgements}

One of the authors (RT) is thankful to Dr Gary Edson, Director of the Texas Tech University Museum (2009) for granting permission to study the Antarctic plant fossils and for providing hospitality during a short visit. The research was funded by the National Science Foundation and Birbal Sahni Institute of Palaeobotany.

\section{References}

Ahmed, F.E., Hall, A.E., and DeMason, D.A., 1992, Heat Injury during floral development in Coupea (Vigna unguiculata, Fabaceae): American Journal of Botany, v. 79, pp. 784-791.

Axelrod, D., 1981, Role of volcanism in climate and evolution: Geological Society of America Special Paper, v.185, 59 p.
Balance, P.F., 1977, The Beacon Super Group in the Allan Hills, Central Victoria Land, Antarctica: New Zealand Journal of Geology and Geophysics, v. 20, pp. 1003-1016

Bird, M.I., 1997, Fire in the Earth Sciences: Episodes, v. 20, no.4, pp. 223226.

Barrett, P.J., and Kohn, B.P., 1975, Changing sediment and transport directions from Devonian to Triassic in the Beacon Supergroup of south Victoria Land, Antarctica; in Campbell, K S W, eds, Gondwana Geology: Australian National University Press, pp. 605-614.

Barrett, P.J., Kohn, B.P., Askin, R., and McPherson, J.G., 1971, Preliminary report on Beacon Supergroup studies between Hatherton and Mackay Glaciers, Antarctica: New Zealand Journal of Geology and Geophysics, v. 14 , pp. 605-614.

Blong, R.G., and Gillespie, R., 1978, Fluvially transported charcoal gives erroneous ${ }^{14} \mathrm{C}$ ages for recent deposits: Nature, v. 271, pp. 739-741.

Borns, H.W., Jr. and Hall, B.A., 1969, Mawson "tillite" in Antarctica: Preliminary report of a volcanic deposit of Jurassic age: Science, v. 166, pp. 870-872.

Bostic, N.H., 1971, Thermal alteration of clastic organic particles as an indicator of contact and burial metamorphism in sedimentary rocks: Geoscience and Man, v. 3, pp. 83-92

Boucher, L.D, Taylor, E.L., and Taylor, T.N., 1993, Dicroidium from the Triassic of Antarctica. In: Lucas, S.G. and Morales, M. (Editors), The Non Marine Triassic, New Mexico; Museum Natural History Science Bulletin, v. 3, pp.39-46.

Cantrill, D.J., Drinnan, A.N., and Webb, J.A., 1995, Late Triassic Plant Fossils from the Prince Charles Mountains, East Antarctica: Antarctic Science, v. 7, pp. 51-62.

Chatterjee, S., Borns, Jr. H. W., and Hotton III, N., 1983, Gondwana rocks of the Allan Hills: Antarctic Journal of the United States, v. 18, pp. 2224.

Cope, M.J., 1993, A preliminary stydy of Charcoalified plant fossils from the Middle Jurassic Scalby Formation of North Yorkshire: Special Paper in Palaeontology, v. 49, pp. 101-111.

Cressler, W.L., 2001, Evidences of Earliest Known Wildfires: Palaios, v. 16, no. 2, pp. 171-174.

Edwards, D. and Axe, L., 2004, Anatomical Evidence in the Detection of the Earliest Wildfires: Palaeois, v. 19, pp. 113-128.

Elliot, D.H., Habun, M.A., and Siders, M.A., 1986, The Exposure Hill Formation, Mesa Range, in Stump, E, ed, Geological investigations in Northern Victoria Land, Antarctica: Contributions Mineralogy and Petrology, v. 121, pp. 217-236.

Finkelstein, D.B., Pratt, L.M., Curtin, T.M., and Brasell, S.C., 2005, Wild fires and seasonal aridity recorded in Late Cretaceous Strata from South eastern Arizona, U.S.A.: Sedimentology, v. 52, pp. 587-599.

Glasspool, I.J., Edwards, D., and Axe, L., 2004, Charcoal in the Silurian as evidence for the earliest wildfire: Geology, v. 32, pp. 381-383.

Gray, J., and Boucot, A.J., 1975, Colour Changes in Pollen and Spores: A Review: Bulletin Geological Society of America, v .86, pp. 1019-1033

Gunn, B.M., and Warren, G., 1962, Geology of Victoria Land between the Mawson and Mulock Glaciers, Antarctica: New Zealand Geological Survey Bulletin, v. 7, pp. 1-157.

Jasper, A., Uhl, D., Guerra-Sommer, M., and Mosbrugger, V., 2008, Palaeobotanical evidences of widfires in the Late Palaeozoic of South America-Early Permian, Rio Bonito Formation, Paraná Basin, Rio Grande do Sul, Brazil: Journal of South American Earth Sciences, v 26, pp. 435-444.

Kedves, M., Borbola, A., Tripathi, S.K.M. and Kumar, M., 2000, Thermal effect on some extant Palm pollen: Plant Cell Biology and Devlopment, Hungary, v. 11, pp. 166-183.

Kedves, M. Hegedûs, A. and Oláh, I., 1992, High temperature effect of some bisaccate gymnosperm pollen grains: Plant Cell Biology and Devlopment, Hungary, v. 3, pp. 14-37.

Kemp, T.S., 1999, Fossil and Evolution: Oxford University Press, Oxford, pp. 280

Kyle, R.A., 1977, Palynostratigraphy of the Victoria Group of South Victoria 
Land, Antarctica: New Zealand Journal of Geology and Geophysics, v. 20, pp.1081-1102.

Lupia, R., 1995, Palaeobotanical Data from Fossil Charcoal: An Actualistic Study of Seed Plant Reproductive Structures: Palaios, v. 10, pp. 465477.

Nichlos, G., and Jones, T., 1992, Fusain in Carboniferous shallow marine sediments, Donegal Ireland: the sedimentological effects of wildfire: Sedimentology, v. 39, pp. 487-502.

Mishra, H.K., 1996, Comparative petrological analysis between the Permian coals of India and Western Australia: paleoenvironments and thermal history: Palaeogeography Palaeoclimatology Palaeoecology, v. 125, pp.199-216.

Mishra, H.K., Chandra, T.K. and Verma, R.P., 1990, Petrology of Permian coals of India: International Journal of Coal Geology, v. 16, pp. 47-71.

Patterson III, W.A., Edwards, K.J. and Maguire, D.J., 1987, Microscopic Charcoal as an indicator of fire: Quaternary Science Review, v. 6, pp. 323.

Pompilio, M., Armienti, P., and Tamponi, M., 2001, Petrography, Mineral Composition and Geochemistry of Volcanic and Subvolcanic Rocks of CRB-3, Victoria Land Basin, Antarctica: Terra Antarctica, v. 8, pp. 469480 .

Riley, T.R. and Knight, K.B., 2001, Review: Age of pre-break up Gondwana Magmatism: Antarctic Science, v. 13, no. 2, pp. 99-110.

Riley, T.R., and Leat, P.T., 1999, Large volume siliceous volcanism along the Proto-Pacific margin of Gondwana: lithological and stratigraphical investigations from the Antarctic Peninsula: Geological Magzine, v. 136, pp. 1-16.

Schöner, R., Viereck-Goette, L, Schneider, J., and Bomfleur, B., 2007, TriassicJurassic sediments and multiple volcanic events in North Victoria Land: United. States Geological Survey and The National Academies; USGS of -2007-1047, Short Research Paper, v.102, pp. 1-5, doi 10.3133,2007, pp.1-5.

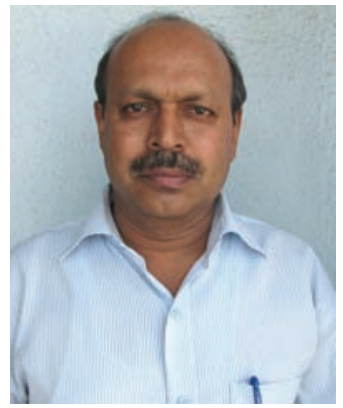

Madhav Kumar is Scientist ' $E$ ' at the Birbal Sahni Institute of Palaeobotany, Lucknow. He has been working on Palynostratigraphy and Palynofacies analysis of Phanerozoic sedimentary basins especially of northeast and central India. His main interest covers characterization of palynoflora of CretaceousTertiary and plant derived sedimentary organic matter, their taxonomy and determination of depositional environment.

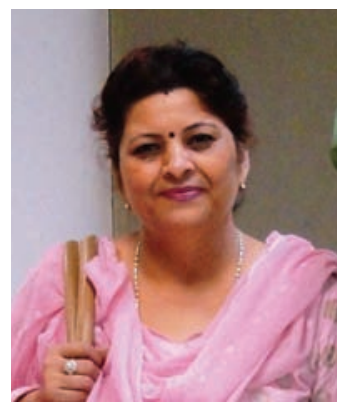

Rajni Tewari is Scientist ' $E$ ' at Birbal Sahni Institute of Palaeobotany, Lucknow India. Her main research interests include Palaeozoic plant megafossils, Gondwana megaspores, cuticular studies including dispersed angiospermous cuticles from Tertiary of north east India, palaeoclimate and biostratigraphy. Her current research focuses on Gondwana plant fossils from India, Antarctica and Brazil, their comparative study, evolution and palaeoclimate.
Scott, A.C., 2000, The Pre-Quaternary history of fire: Palaeogeography Palaeoclimatology Palaeoecology, v. 164, pp. 281-329.

Scott, A.C., and Glasspool, I. J., 2007, Observation and experiments on the origin and formation of inertinite group macerals: International Journal Coal Geology, v. 70, pp. 53-66.

Scott, A.C. and T.P. Jones, 1994, The nature and influence of fire in Carboniferous ecosystems. Palaeogeography, Palaeoclimatology, Palaeoecology, v. 106, pp. 91-112.

Shu, O., Xi-Guang, D., Yan-Bin, S., Xiang-Shen, Z. and Xiao-Han, L., 2000, Late Triassic plant microfossil from Miers Bluff Formation of Livingston Island, South Shetland Island, Antarctica: Antarctic Science, v. 12, pp. 217-228.

Spalletti, L.A., Artabe, A.E., and Morel, E., 2003, Geological factors and Evolution of Southern Gondwana Triassic Plants: Gondwana Research, v. 6, pp.119-134.

Stopes, M.C., 1919, On the four visible ingredients in banded bituminous coal: Proceedings of the Royal Society, Series B, v. 90, pp. 470-487.

Uhl, D., Louseberg, S., Noll, R., and Stapf, K.R.G., 2004, Widfires in the Late Palaeozoic of Central Europe-an overview of the Rotleigend (Upper Carboniferous-Lower Permian) of the Saar-Nahe Basin (SW Germany): Palaeogeography Palaeoclimatoogy Palaeoecology, v. 62, pp. 361-386.

Ujiié, Y., Arata, Y., and Sugawara, M,. 2003, Heating experiments on Pinus pollen grains and its relation to petroleum genesis: Geochemical Journal, v. 37 , pp $367-376$

Van de Schootbrugge, B., Quan, T.M., Lindström, S., Püttman, W., Heunisch, C, Pross, J., Fiebig, J., Petschick, R., Röhling, R., Röhling, H.-G., Richoz, S., Rosenthal, Y., and Falkowski, P.G., 2009, Floral changes across the Triassic/Jurassic boundary linked to flood basalt volcanism: Nature Geoscience, v. 2, pp. 589-594

Whitlock, C., and Larsen, C., 2001, Charcoal as a Fire Proxy. In: Smol, J.P, Birks, H.J.B. and Last, W.M. (Eds), Tracking Environmental Change Using Lake Sediments. Vol. 3, Terrestrial, Algal and Siliceous Indicators: Kluwer Academic Publishers, Dordrecht, The Netherlands, pp. 75-97.

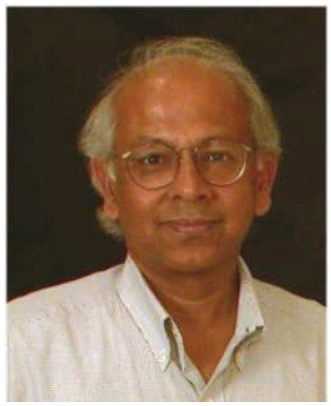

Sankar Chatterjee is Paul Whitfield Horn Professor of Geology and Curator of Paleontology at Texas Tech University. He was a visiting professor at university of California, Berkeley in 1976 and a postdoctoral researcher at the Smithsonian Institution from 1977 to 1978 . His current research focuses on Mesozoic vertebrates, flight of pterosaurs and birds, origin of flight, mass extinction, macroevolution, plate tectonics, and paleobiogeography.

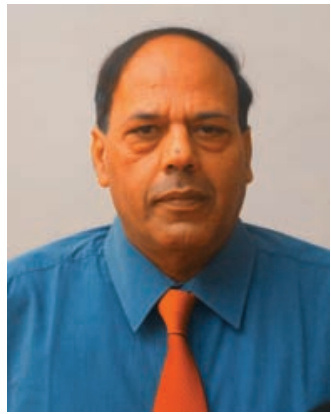

Naresh C. Mehrotra is Director, Birbal Sahni Institute of Palaeobotany (BSIP), Lucknow which is affiliated to Department of Science and Technology, Government of India. Earlier, he was associated with Oil and Natural Gas Corporation Limited (ONGC) and Wadia Institute of Himalayan Geology, Dehradun. He also worked at the University of Saskatchewan, Canada (1982-1984). His expertise includes application of high impact palynology in hydrocarbon exploration. 